\title{
AKIBAT HUKUM PEMBATALAN PERKAWINAN DI PENGADILAN AGAMA KABUPATEN TULUNGAGUNG (Studi Perkara No : 0554/PDT.G/2009/PA.TA dan Perkara No : 0845/PDT.G/2010/PA.TA)
}

\author{
A. Hasyim Nawawie \\ Fakultas Syari'ah Institut Agama Islam Negeri (IAIN) Tulungagung
}

\begin{abstract}
The cancellation of the marriage begins after the Court's decision has binding legal force and effect since the time of the marriage. The decision to revoke the marriage does not apply retroactively to the children born of the marriage. Act No. 1 of 1974 Article 22 on Marriage states that marriage annulment can be done , if the parties do not qualify into marriage means that marriage is prohibited if not meeting the requirements of marriage and marriage can be canceled.

The reality in the society there are still people who are performing marriages when there are conditions that are not fulfilled or there are prohibitions have been violated as a marriage annulment cases occurred in the Religious Court in Tulungagung, in case Number : 0554 /Pdt. G/ 2009 / PA.TA in this case the applicant who serves as his wife reported her husband to the lawsuit marriage because it alleged that between them they have no blood ties that the defendant is the little brother of the father Bulik applicant or applicants who are forbidden to marry by Sya r'i and Legal OF . Further than this marriage itself had been born a boy and also acquired the joint property in the form of vehicles, household furniture, and some money. The court in this case has decided to grant the request for the applicant to make a decision in the form of cancellation of marriage.

In the second case, the cancellation of marriage occurs in case Number: 0845 / Pdt.G / 2010 / PA.TA. In the case of an applicant who works as a maid servant marriage registrar to apply for annulment of marriage to couples who were suspected of committing the practice of polyandry, in which the wife is known to still married to another man before. Further than this marriage itself had been born a girl and also acquired the joint property in the form of a sum of money. After checking the case the court decided to grant the petition of the applicant to make a decision in the form of cancellation of marriage.

This ruling brings legal consequences against the husband and wife whose marriage was canceled covering their legal status, legal status of children, and the status of property obtained during marriage after a court decision on the cancellation of the marriage. The problems that arise are the Marriage Law and the Compilation of Islamic Law does not regulate explicitly on the legal status as a result of the cancellation of the marriage related about the legal status of husband and wife whose marriage is canceled, the legal status of child care and the legal status of property obtained during marriage after the entry into force of a court decision on the cancellation of the marriage.
\end{abstract}

Keywords : Cancellation of Marriage, A Result Of The Law, The Legal Status. 


\section{ABSTRAK}

Batalnya perkawinan dimulai setelah keputusan Pengadilan mempunyai kekuatan hukum yang tetap dan berlaku sejak saat berlangsungnya perkawinan. Keputusan pembatalan perkawinan tidak berlaku surut terhadap anak-anak yang dilahirkan dari perkawinan tersebut. Undang-undang Nomor 1 Tahun 1974 Pasal 22 tentang Perkawinan menyatakan bahwa pembatalan perkawinan dapat dilakukan, bila para pihak tidak memenuhi syarat melangsungkan perkawinan berarti bahwa perkawinan itu dilarang bila tidak memenuhi syarat-syarat perkawinan dan perkawinannya dapat dibatalkan.

Kenyataan dalam masyarakat masih ada orang-orang yang melaksanakan perkawinan padahal ada syarat-syarat yang tidak terpenuhi atau ada laranganlarangan yang telah dilanggar seperti kasus pembatalan perkawinan terjadi di wilayah Pengadilan Agama Kabupaten Tulungagung, yaitu pada perkara Nomor: 0554 /Pdt.G/2009/PA.TA pada perkara ini pemohon yang berkedudukan sebagai istri melaporkan suaminya dengan gugatan pembatalan perkawinan karena ditengarai bahwa di antara mereka masih ada hubungan darah yaitu termohon adalah adik kandung ayah pemohon atau bulik pemohon yang dilarang untuk menikah secara Sya r'i dan Undang-undang. Lebih jauh dari perkawinan ini sendiri telah lahir seorang anak laki laki dan juga diperoleh harta bersama berupa kendaraan, perabot rumah tangga, dan sejumlah uang. Pengadilan dalam perkara ini telah memutuskan untuk mengabulkan permohonan pemohon dengan menjatuhkan putusan berupa pembatalan perkawinan.

Pada kasus kedua, pembatalan perkawinan terjadi pada perkara Nomor: 0845/Pdt.G/2010/PA.TA. Pada perkara tersebut pemohon yang berprofesi sebagai pembantu pegawai pencatat nikah mengajukan permohonan pembatalan perkawinan terhadap pasangan suami istri yang ditengarai melakukan praktek poliandri, di mana pihak istri diketahui masih terikat perkawinan dengan pria lain sebelumnya. Lebih jauh dari perkawinan ini sendiri telah lahir seorang anak perempuan dan juga diperoleh harta bersama berupa sejumlah uang. Setelah memeriksa perkara tersebut pengadilan kemudian memutuskan untuk mengabulkan permohonan pemohon dengan menjatuhkan putusan berupa pembatalan perkawinan.

Putusan ini membawa akibat hukum terhadap pihak suami dan istri yang perkawinannya dibatalkan meliputi status hukum mereka, status hukum pengasuhan anak, dan status harta yang diperoleh saat perkawinan setelah putusan pengadilan tentang pembatalan perkawinan. Permasalahan yang muncul adalah Undang-undang Perkawinan maupun Kompilasi Hukum Islam tidak mengatur secara eksplisit tentang status hukum akibat pembatalan perkawinan yang berkaitan tentang status hukum suami dan istri yang perkawinannya dibatalkan, status hukum pengasuhan anak dan status hukum harta yang diperoleh saat perkawinan setelah berlakunya putusan pengadilan tentang pembatalan perkawinan.

Kata kunci : Pembatalan Perkawinan, Akibat Hukum, Status Hukum 


\section{A. PENDAHULUAN}

\section{Latar Belakang Masalah}

Pelaksanaan perkawinan memberikan tambahan hak dan kewajiban pada seseorang, baik dalam kehidupan pribadi, keluarga maupun masyarakat. Namun demikian dengan berubahnya status seseorang akibat dari perkawinan tersebut belum berarti seseorang telah mengerti hak-hak dan kewajibannya dalam hubungan perkawinan tersebut. Berkaitan dengan tujuan dari pelaksanaan perkawinan, diperlukan adanya peraturanperaturan yang akan menjadi dasar dan syarat yang harus dipenuhi sebelum dilaksanakannya perkawinan.

Batalnya perkawinan dimulai setelah keputusan Pengadilan mempunyai kekuatan hukum yang tetap dan berlaku sejak saat berlangsungnya perkawinan.Keputusan pembatalan perkawinan tidak berlaku surut terhadap anak-anak yang dilahirkan dari perkawinan tersebut. Undang-undang Nomor 1 Tahun 1974 Pasal 22 tentang Perkawinan menyatakan bahwa pembatalan perkawinan dapat dilakukan, bila para pihak tidak memenuhi syarat melangsungkan perkawinan berarti bahwa perkawinan itu dilarang bila tidak memenuhi syarat-syarat perkawinan dan perkawinannya dapat dibatalkan. Penjelasan kata "dapat" dalam pasal ini bisa diartikan bisa batal atau bisa tidak batal, bilamana menurut ketentuan hukum agamanya masing-masing tidak menentukan lain. Istilah dapat dibatalkan dalam Undang-undang Nomor 1 Tahun 1974 ini berarti dapat dibatalkan dan batal demi hukum. Dengan demikian perkawinan dapat dibatalkan berarti sebelumnya telah terjadi perkawinan, lalu dibatalkan karena adanya pelanggaran terhadap aturan-aturan tertentu. $^{19}$

Pembatalan perkawinan ini terjadi setelah ditemukan pelanggaran terhadap Undang undang Perkawinan atau Hukum Islam. Jika ini terjadi maka Pengadilan Agama dapat membatalkan perkawinan atas permohonan

\footnotetext{
${ }^{19}$ Amir Nuruddin dan Azhari Akmal Tarigan, 2004, Hukum Perdata Islam di Indonesia Studi Kritis Perkembangan Hukum Islam dari Fikih, UU No.1/1974, sampai KHI, Jakarta: Kencana, hlm. 106-107.
} 
pihak-pihak yang berkepentingan. Pada Undang-undang Nomor 1 Tahun 1974 Pasal 23 menyebutkan bahwa pihak-pihak yang dapat mengajukan pembatalan perkawinan adalah para keluarga dalam garis keturunan lurus ke atas dari suami atau istri, suami atau istri, pejabat yang berwenang hanya selama perkawinan belum diputuskan, dan pejabat yang ditunjuk tersebut Ayat (2) Pasal 16. Namun apabila pihak yang dirugikan tidak membatalkan perkawinan tersebut, maka perkawinan tersebut tetap berlangsung.

Perkawinan dapat batal demi hukum dan bisa dibatalkan oleh pengadilan. Secara sederhana ada dua sebab terjadinya pembatalan perkawinan. Pertama, pelanggaran prosedural perkawinan. Kedua, adanya pelanggaran terhadap materi perkawinan. Contoh yang pertama, tidak terpenuhi syarat-syarat wali nikah, tidak dihadiri para saksi dan alasan prosedural lainnya. Sedangkan contoh yang kedua adalah perkawinan dilangsungkan di bawah ancaman, atau terjadi salah sangka mengenai calon suami dan istri. ${ }^{20}$

Kenyataan dalam masyarakat masih ada orang-orang yang melaksanakan perkawinan padahal ada syarat-syarat yang tidak terpenuhi atau ada larangan-larangan yang telah dilanggar. Misalnya, salah satu pihak masih terikat dalam perkawinan, kemudian melangsungkan perkawinan baru tanpa sepengetahuan atau tanpa seizin istri pertama. Bahkan tidak mengetahui prosedur dari melaksanakan perkawinan maupun tata cara dari pembatalan perkawinan, sehingga akibatnya melahirkan perkawinan di bawah tangan, kawin siri, ataupun perkawinan yang tidak melengkapi syarat-syarat dari perkawinan. ${ }^{21}$ Seperti halnya perceraian, pembatalan perkawinan ternyata membawa konsekuensi yang tidak jauh berbeda dengan masalah perceraian, yaitu berupa status para pihak yang berperkara, status hukum pengasuhan anak, dan harta bersama yang diperoleh selama masa perkawinan.

${ }^{20}$ Ibid, hlm. 107-108

${ }^{21}$ Muhammad Idris, 1996, Hukum Perkawinan Islam: Suatu Analisis dari Undang-Undang Nomor 1 Tahun 1974 dan Kompilasi Hukum Islam, Jakarta: Bumi Aksara, hlm. 86 
Kasus pembatalan perkawinan terjadi di wilayah Pengadilan Agama Kabupaten Tulungagung, yaitu pada perkara Nomor: 0554 /Pdt.G/2009/PA.TA Pada perkara ini pemohon yang berkedudukan sebagai istri melaporkan suaminya dengan gugatan pembatalan perkawinan karena ditengarai bahwa di antara mereka masih ada hubungan darah yaitu termohon adalah adik kandung ayah pemohon atau bulik pemohon yang dilarang untuk menikah secara Syar'i dan Undang-undang. Dari perkawinan ini sendiri telah lahir seorang anak laki laki dan juga diperoleh harta bersama berupa kendaraan, perabot rumah tangga, dan sejumlah uang. Pengadilan dalam perkara ini setelah memeriksa perkara tersebut berdasarkan bukti dan saksi yang ada, maka pengadilan memutuskan untuk mengabulkan permohonan pemohon dengan menjatuhkan putusan berupa pembatalan perkawinan.

Pada kasus kedua, pembatalan perkawinan terjadi pada perkara Nomor: 0845/Pdt.G/2010/PA.TA. Pada perkara tersebut pemohon yang berprofesi sebagai pembantu pegawai pencatat nikah mengajukan permohonan pembatalan perkawinan terhadap pasangan suami istri yang ditengarai melakukan praktek poliandri, di mana pihak istri diketahui masih terikat perkawinan dengan pria lain sebelumnya. Dari perkawinan ini sendiri telah lahir seorang anak perempuan dan juga diperoleh harta bersama berupa sejumlah uang. Setelah memeriksa perkara tersebut berdasarkan bukti dan saksi yang ada, maka pengadilan kemudian memutuskan untuk mengabulkan permohonan pemohon dengan menjatuhkan putusan berupa pembatalan perkawinan.

Putusan ini membawa akibat hukum terhadap pihak suami dan istri yang perkawinannya dibatalkan meliputi status hukum mereka, status hukum pengasuhan anak, dan status harta yang diperoleh saat perkawinan setelah putusan pengadilan tentang pembatalan perkawinan. Permasalahan yang muncul adalah Undang-undang Perkawinan maupun Kompilasi Hukum Islam tidak mengatur secara eksplisit tentang status hukum akibat pembatalan perkawinan yang berkaitan tentang status hukum suami dan 
istri yang perkawinannya dibatalkan, status hukum pengasuhan anak, dan status hukum harta yang diperoleh saat perkawinan setelah berlakunya putusan pengadilan tentang pembatalan perkawinan.

Status hukum yang dimaksud di sini adalah berkenaan dengan status seseorang setelah perkawinannya dibatalkan. Bagi pihak perempuan adalah apakah berstatus perawan atau janda. Sedangkan bagi pihak laki laki adalah apakah berstatus jejaka atau duda. Permasalahan kasus pembatalan perkawinan menjadi menarik disebabkan kasus pembatalan perkawinan tidak dapat disamakan dengan kasus perceraian, di mana dalam kasus pembatalan perkawinan tidak terdapat adanya surat akta cerai.

Berkenaan dengan akibat hukum terhadap anak pembatalan perkawinan juga membawa akibat hukum terhadap hak pengasuhan anak setelah pembatalan perkawinan. Permasalahan di sini adalah bagaimana dengan hak pengasuhan anak, siapa yang berhak mengasuh dan memelihara. Dalam kasus pembatalan perkawinan tidak ditemukan dalam Undang-undang Perkawinan maupun Kompilasi Hukum Islam mengenai status hukum pengasuhan anak.

Pembatalan perkawinan juga akan membawa akibat hukum terhadap harta bersama yang diperoleh oleh suami istri selama masa perkawinan, karena belum ada aturan yang khusus yang mengatur tentang pembagian harta bersama dalam pembatalan perkawinan. Menurut Undang-undang Nomor 1 Tahun 1974 Pasal 35 menyebutkan tentang harta benda yang diperoleh selama perkawinan menjadi harta bersama. Harta bawaan dari masing - masing suami dan isteri dan harta benda yang diperoleh oleh masing - masing sebagai hadiah atau warisan adalah di bawah penguasaan masing - masing sepanjang para pihak tidak menentukan lain. Karena pembatalan perkawinan tidak sama dengan perceraian, tentunya terdapat perbedaan dalam hal pembagian harta bersama, karena di dalam Undangundang tidak diatur mengenai penyelesaian pembagian harta bersama dalam pembatalan perkawinan. 


\section{Rumusan Masalah}

a. Bagaimana akibat hukum putusan pembatalan perkawinan oleh Pengadilan Agama Kabupaten tulungagung terhadap status suami dan istri pada perkara nomor: 0554 /Pdt.G/2009/PA.TA dan perkara nomor 0845/Pdt.G/2010/PA.TA.

b. Bagaimana akibat hukum putusan pembatalan perkawinan oleh Pengadilan Agama Kabupaten Tulungagung terhadap pengasuhan anak pada perkara nomor:0554/Pdt.G/2009/PA.TA dan perkara nomor 0845/Pdt.G/2010/PA.TA.

c. Bagaimana akibat hukum putusan pembatalan perkawinan oleh Pengadilan Agama Kabupaten Tulungagung terhadap harta yang diperoleh selama masa perkawinan pada perkara nomor: 0554 /Pdt.G/2009/PA.TA dan perkara nomor 0845/Pdt.G/2010/PA.TA.

\section{Tujuan Penelitian}

a. Mengetahui akibat hukum putusan pembatalan perkawinan oleh Pengadilan Agama Kabupaten tulungagung terhadap status suami dan istri pada perkara nomor: 0554 /Pdt.G/2009/PA.TA dan perkara nomor 0845/Pdt.G/2010/PA.TA.

b. Menelaah secara mendalam tentang akibat hukum putusan pembatalan perkawinan oleh Pengadilan Agama Kabupaten Tulungagung terhadap pengasuhan anak pada perkara Nomor:0554/Pdt.G/2009/PA.TA dan perkara nomor 0845/Pdt.G/2010/PA.TA.

c. Menelaah secara mendalam tentang akibat hukum putusan pembatalan perkawinan oleh Pengadilan Agama Kabupaten Tulungagung terhadap harta yang diperoleh selama masa perkawinan pada perkara nomor: 0554 /Pdt.G/2009/PA.TA dan perkara Nomor 0845/Pdt.G/2010/PA.TA 


\section{B. PEMBAHASAN}

\section{Konsep Pembatalan Perkawinan}

Dalam Kompilasi Hukum Islam (KHI) permasalahan pembatalan perkawinan dijelaskan secara rinci pada Pasal 70 sampai 76. Dalam Pasal 70 KHI dinyatakan bahwa perkawinan batal (batal demi hukum) apabila :

a. Perkawinan dilakukan antara dua orang yang mempunyai hubungan darah, semenda, sesusuan, sampai derajat tertentu yang menghalangi perkawinanmenurut Pasal 8 Undang-undang Nomor 1 Tahun 1974 yaitu : berhubungan darah dalam garis lurus kebawah atau keatas, berhubungan darah dalam garis lurus keturunan menyamping, bersemenda yaitu mertua, anak tiri, dan ibu atau ayah tiri, berhubungan susuan yaitu orang tua susuan, anak susuan, dan bibi atau paman susuan, istri adalah saudara kandung atau sebagai bibi atau kemenakan dari istri atau istriistrinya.

b. Seseorang menikahi bekas istrinya yang telah di li'annya

c. Seseorang menikahi bekas istrinya yang telah dijatuhi 3 kali talak oleh dirinya. kecuali jika bekas istrinya sudah menikah lagi dengan pria lain yang kemudian bercerai lagi ba'da dukhul dari pria tersebut dan telah habis masa iddahnya. ${ }^{22}$

Selanjutnya pada pasal 71 dijelaskan perkawinan yang dapat dibatalkan apabila : a), seorang suami melakukan poligami tanpa izin Pengadilan Agama, b). perempuan yang dikawini ternyata kemudian diketahui masih menjadi istri pria yang mafqud, c). perempuan yang dikawini ternyata masih dalam masa iddah dari suuami lian, d). perkawinan yang melanggar batas umur perkawinan, sebagaimana ditetapkan Pasal 7 Undang-undang nomor 1 Tahun 1974, e). perkawinan

${ }^{22}$ Amir Syarfuddin, Hukum Perkawinan Islam di Indonesia, Antara Fiqh Munakahat, dan Undang-undang Perkawinan, hlm. 253 
dilangsungkan tanpa wali atau dilaksanakan oleh wali yang tidak berhak, f). perkawinan yang dilaksanakan dengan paksaan. ${ }^{23}$

Berkenaan dengan pihak-pihak yang dapat membatalkan perkawinan diatur dalam KHI Pasal 73 yaitu para keluarga dalam garis keturunan lurus keatas, kebawah baik dari pihak suami atau pun istri; suami istri; pejabat yang berwenang mengawasi pelaksanaan perkawinan menurut undangundang; para pihak yang berkepentingan yang mengetahui adanya cacat dalam rukun dan syarat perkawinan menurut hukum Islam dan peraturan perundang-undangan sebagaimana tersebut dalam Pasal 67. Adapun menyangkut saat mulai berlakunya pembatalan perkawinan yaitu setelah keputusan pengadilan Agama yang mempunyai ketetapan hukum tetap dan berlaku sejak saat berlangsungnya perkawinan (KHI Pasal 74 Ayat (2).

Pembatalan perkawinan tentunya mempunyai akibat hukum yang ditimbulkan setelahnya. Dalam Undang-undang Nomor 1 Tahun 1974 Pasal 28 Ayat (2) dinyatakan bahwa keputusan pembatalan perkawinan tidak berlaku surut terhadap: a), anak-anak yang dilahirkan dari perkawinan tersebut, b). suami atau istri yang bertindak dengan beriktikad baik kecuali terhadap harta bersama, bila pembatalan perkawinan didasarkan adanya perkawinan lain yang lebih dahulu, dan c). orang-orang ketiga lainnya tidak termasuk dalam huruf $a$, dan $b$ sepanjang mereka memperoleh hak-hak dengan Iktikad baik sebelum keputusan tentang pembatalan mempunyai kekuatan hukum tetap. ${ }^{24}$

Adapun dalam KHI akibatnya tersebut disebutkan dalam Pasal 75 dan 76. Dalam Pasal 75 disebutkan bahwa keputusan pembatalan perkawinan tidak berlaku surut terhadap perkawinan yang batal karena salah satu dari suami istri murtad, anak-anak yang dilahirkan dari

${ }^{23}$ Abdurrahman, Kompilasi Hukum Islam di Indonesia, Jakarta: Akademika Pressindo, 1995, hlm. 130

${ }_{24}$ Amiur Nuruddin, dan Azhari Akmal Tarigan, Hukum Perdata Islam Di Indonesia, Studi Kritis Perkembangan Hukum Islam dari Fikih, UU No. 1/1974 Sampai KHI, ( Jakarta: Kencana, 2006), cet ke-III, h.. 113 
perkawinan tersebut, pihak ketiga sepanjang mereka memperoleh hak-hak dengan itikad baik sebelum keputusan pembatalan perkawinan mempunyai kekuatan hukum tetap. Sedangkan dalam Pasal 76 KHI disebutkan bahwa batalnya suatu perkawinan tidak akan memutuskan hubungan hukum antara anak dengan orang tuanya.

Terkait dengan akibat hukum pembatalan perkawinan, kiranya perlu kita cermati permasalahan yang berkenaan dengan saat mulai berlakunya pembatalan perkawinan dimuat di dalam Pasal 28 Ayat (1), sebagai berikut: Batalnya suatu perkawinan dimulai setelah keputusan Pengadilan mempunyai kekuatan hukum yang tetap dan berlaku sejak saat berlangsungnya perkawinan.

a. Terhadap Anak

Selanjutnya permasalahan yang berkenaan dengan akibat hukum terhadap pembatalan perkawinan di muat dalam Pasal 28 Ayat (2), sebagai berikut: Keputusan tidak berlaku surut terhadap (1) Anak-anak yang dilahirkan dari perkawinan tersebut; (2) Suami atau isteri yang bertindak dengan iktikad baik, kecuali terhadap harta bersama, bila pembatalan perkawinan didasarkan atas adanya perkawinan lain yang lebih dahulu; (3) Orang-orang ketiga lainnya tidak termasuk dalam a dan b sepanjang mereka memperoleh hak-hak dengan iktikad baik sebelum keputusan tentang pembatalan mempunyai kekuatan hukum tetap.

Sayuti Tholib memberikan ulasan terhadap Pasal 28 Ayat (2) sebagai berikut :

"Keputusan tidak berlaku surut terhadap anak-anak yang dilahirkan dari perkawinan tersebut. Anak-anak yang dilahirkan dalam perkawinan yang telah dibatalkan tidak berlaku surut, sehingga dengan demikian anak-anak ini dianggap sah, meskipun salah seorang tuanya beritikad atau keduanya beritikad buruk. Dalam BW bila kedua orang tuanya beritikad baik, atau salah seorang dari orang tuanya yang beritikad baik, maka anak yang dilahirkan dalam perkawinan yang dibubarkan ini, disahkan. Sedangkan bagi mereka yang kedua orang tuanya 
beritikad buruk, maka anank-anaknya dianggap anak luar kawin, dan dianggap tidak ada perkawinan. Dalam Undang-undang Nomor.1 Tahun 1974 lebih adil kiranya bahwa semua anak yang dilahirkan, dalam perkawinannya yang dibatalkan, meskipun kedua orang tuanya beritikad buruk anak tersebut masih anak sah.,25

Ini berdasarkan kemanusiaan dan kepentingan anak-anak yang tidak berdosa, patut mendapatkan perlindungan hukum. Dan tidak seharusnya bila anak-anak yang tidak berdosa harus menanggung akibat tidak mempunyai orang tua, hanya karena kesalahan orang tuanya, dengan demikian menurut Undangundang Nomor 1 Tahun 1974 anak-anak yang dilahirkan itu mempunyai status hukum yang jelas sebagai anak sah dari kedua orang tuanya yang perkawinannya dibatalkan.

b. Terhadap Harta yang Diperoleh Selama Perkawinan

Suami atau isteri yang bertindak dengan iktikad baik, kecuali terhadap harta bersama, bila pembatalan perkawinan didasarkan atas adanya perkawinan lain yang lebih dahulu.

Pembahasan mengenai harta yang ada pada dan sebelum perkawinan serta setelah pembatalan perkawinan merupakan masalah yang perlu mendapatkan pemahaman mendalam, karena ini salah satu hal yang menyangkut perlindungan hak dan kewajiban para pihak.

Sebelum membicarakan harta kekayaan suami isteri dalam perkawinan, terlebih dahulu harus dilihat mengenai kedudukan harta orang Islam secara umum. Dalam bidang harta kekayaan seseorang dan cara penyatuan atau penggabungan harta tersebut dengan harta orang lain dikenal dengan nama syirkah atau syarikah.

Di lihat dari asal-usulnya harta suami istri itu dapat digolongkan pada tiga golongan ;

${ }^{25}$ Sayuti Thalib, Hukum Kekeluargaan Indonesia, UI, Jakarta, hlm. .83-84 
1) Harta masing-masing suami isteri yang telah dimilikinya sebelum mereka kawin baik berasal dari warisan, hibah atau usaha mereka sendiri-sendiri atau dapat disebut harta bawaan.

2) Harta masing-masing suami isteri yang dimilikinya sesudah mereka berada dalam hubungan perkawinan, tetapi diperolehnya bukan dari usaha mereka baik seorang-seorang atau bersama-sama, tetapi merupakan hibah, wasiat atau warisan untuk masing-masing.

3) Harta yang diperoleh sesudah mereka berada dalam hubungan perkawinan atas usaha mereka berdua atau usaha salah seorang mereka atau disebut harta pencarian. $^{26}$

Dilihat dari sudut hubungan harta dengan perorangan dalam masyarakat, harta itu akan berupa:

1) Harta milik bersama

2) Harta milik seseorang tetapi terikat kepada keluarga

3) Harta milik seseorang dan pemilikan dengan tegas oleh yang bersangkutan

Pada dasarnya harta suami dan harta istri terpisah, baik harta bawaannya masing-masing atau harta yang diperoleh oleh salah seorang suami isteri atas usahanya sendiri-sendiri maupun harta hibah yang diperoleh oleh salah seorang mereka karena hadiah atau hibah atau warisan sesudah mereka terikat dalam hubungan perkawinan.

Walaupun demikian telah dibuka kemungkinan syirkah atas harta kekayaan suami isteri itu secara resmi dan menurut cara-cara tertentu. Suami isteri dapat mengadakan syirkah atas percampuran harta kekayaan yang diperoleh suami dan/atau isteri selama masa adanya perkawinan atas usaha suami atau isteri

${ }^{26}$ Sayuti Thalib, Hukum Kekeluargaan Indonesia, Penerbit UI, Jakarta, hlm. .83-84 
sendiri-sendiri, atau atas usaha mereka bersama-sama. Begitupun mengenai harta kekayaan usaha sendiri-sendiri, sebelum perkawinan dan harta yang berasal bukan dari usaha salah seorang atau bukan dari usaha mereka berdua, tetapi berasal dari pemberian atau warisan atau lainnya yang khusus untuk mereka masing-masing.

Sedangkan dalam Kompilasi Hukum Islam menggariskan bahwa pada dasarnya tidak ada percampuran antara harta suami dan hartaisteri karena perkawinan, adanya harta bersama tidak menutup kemungkinan adanya harta milik masing-masing suami dan isteri ${ }^{27}$ Harta isteri tetap menjadi hak isteri dan dikuasai penuh olehnya, demikian juga harta suami tetap menjadi hak suami dan dikuasai penuh olehnya ${ }^{28}$

Harta bawaan dari masing-masing suami dan isteri dan harta yang diperoleh masing-masing sebagai hadiah atau warisan adalah di bawah penguasaan masing-masing, sepanjang para pihak tidak menentukan lain dalam perjanjian perkawinan.

Suami dan isteri mempunyai hak sepenuhnya untuk melakukan perbuatan hukum atas harta masing-masing berupa hibah, hadiah, sedekah atau lainnya.

Bagi harta kekayaan bersama (gono-gini) merupakan harta bersama yang menjadi milik bersama, hanya saja tidak boleh merugikan pihak yang beritikad baik, bagaimanapun juga pihak yang beritikad baik harus diuntungkan, bahkan bagi pihak yang beritikad buruk harus menanggung segala kerugian-kerugian termasuk bunga-bunga harus ditanggung.

Harta-harta kekayaan yang dibawa oleh pihak yang beritikad baik tidak boleh dirugikan, sedangkan harta kekayaan yang beritikad baik bila ternyata dirugikan, kerugian ini harus

\footnotetext{
${ }^{27}$ Lihat Pasal 85 Kompilasi Hukum Islam

${ }^{28}$ Lihat Pasal 86 ayat (2) Kompilasi Hukum Islam
} 
ditanggung oleh pihak yang beritikad buruk. Dan segala perjanjian perkawinan yang merugikan pihak yang beritikad baik harus dianggap tidak pernah ada.

c. Terhadap Pihak Ketiga

Orang-orang ketiga lainnya tidak termasuk dalam a dan b sepanjang mereka memperoleh hak-hak dengan iktikad baik sebelum keputusan tentang pembatalan mempunyai kekuatan hukum tetap.

Terhadap pihak ketiga yang beritikad baik pembatalan perkawinan tidak mempunyai akibat hukum yang berlaku surut, jadi segala perbuatan perdata atau perikatan yang diperbuat suami isteri sebelum pembatalan perkawinan tetap berlaku, dan ini harus dilaksanakan oleh suami isteri tersebut, sehingga pihak ketiga yang beritikad baik tidak dirugikan.

Bagi anak-anak yang orang tuanya telah dibatalkan perkawinannya mereka tetap merupakan anak sah dari ibu dan bapaknya. Oleh karena itu anak-anak tetap menjadi anak sah, maka status kewarganegaraannya tetap memiliki warganegara bapaknya, dan bagi warisan dan akibat perdata lainnya ia mengikuti kedudukan hukum orangtuanya.

Adapun dalam Pasal 75 Kompilasi Hukum Islam disebutkan bahwa akibat hukum terhadap pembatalan perkawinan tidak berlaku surut terhadap :

1) Perkawinan yang batal karena salah satu dari suami atau isteri murtad

2) Anak-anak yang dilahirkan dari perkawinan tersebut

3) Pihak ketiga sepanjang mereka memperoleh hak-hak dengan beritikad baik, sebelum keputusan pembatalan 
perkawinan mempunyai kedudukan hukum yang tetap. $^{29}$

Pada Pasal 76 disebutkan bahwa batalnya suatu perkawinan tidak akan memutuskan hubungan hukum antara anak dengan orang tuanya. Dengan demikian jelaslah bahwa di dalam Kompilasi Hukum Islam secara eksplisit mengandung dua pengertian pembatalan perkawinan, yaitu perkawinan batal demi hukum seperti yang termuat pada Pasal 70 dan perkawinan yang dapat dibatalkan (relatif) seperti yang terdapat pada Pasal 71. Dan pembatalan perkawinan tidak berpengaruh terhadap status anak yang telah mereka lahirkan seperti yang termuat pada Pasal 76 Kompilasi Hukum Islam.

\section{Akibat Hukum Putusan Pembatalan Perkawinan oleh Pengadilan} Agama Kabupaten Tulungagung Terhadap Status Suami dan Istri

Dalam bab 2 telah dijelaskan bahwa pembatalan perkawinan adalah pembatalan hubungan suami istri sesudah dilangsungkan akan nikah. Oleh karena itu, akan dibahas mengenai akibat hukum pembatalan setelah perkawinan selesai dilangsungkan, dan diketahui adanya syarat-syarat yang tidak terpenuhi menurut KHI maupun undang-undang perkawinan.

Pada perkara pembatalan perkawinan di Pengadilan Agama Kabupaten Tulungagung yaitu perkara Nomor 0845/Pdt.G/2010/PA.TA dan perkara 0554/Pdt.G/2009/PA.TA terdapat perbedaan akibat hukum yang timbul terhadap status suami istri perbedaan tersebut terletak pada perkara Nomor 0554/Pdt.G/2009/PA.TA status hukum suami istri kembali seperti semula yaitu suami menjadi jejaka dan istri menjadi perawan, walupun status hukum suami istri kembali seperti semula namun status sosial tetap menganggap bahwa antara suami istri tersebut statusnya adalah duda dan janda.

Status suami istri setelah perkawinanya dinyatakan batal demi hukum secara implisit tidak dijelaskan dalam Undang-undang Perkawinan

${ }^{29}$ Lihat Pasal 75 Kompilasi Hukum Islam 
Tahun 1974 maupun Kompilasi hukum Islam. Namun dalam hal ini peneliti akan menggunakan pendapat ulama fiqih dalam menganalisis status hukum suami istri setelah perkawinan dibatalkan.

Perkawinan yang telah batal demi hukum maka status perkawinan yang pernah dijalankan dianggap tidak pernah terjadi. Pisahnya suami istri akibat pembatalan perkawinan secara hukum berbeda dengan yang diakibatkan oleh talak. Sebab talak ada talak ba'in dan talak raj'i. Talak raj'i tidak mengakhiri ikatan suami istri dengan seketika. Sedangkan talak ba'in mengakhirinya seketika itu juga. Adapun pembatalan perkawinan baik karena hal-hal yang datang belakangan ataupun karena adanya syaratsyarat yang tidak terpenuhi, maka ia mengakhiri ikatan pernikahan seketika

itu.

Selain itu, pisahnya suami istri yang diakibatkan talak dapat mengurangi bilangan talak itu sendiri. Jika suami menalak istrinya dengan talak raj'i kemudian kembali pada masa iddahnya, atau akad lagi setelah habis masa iddahnya dengan akad baru, maka perbuatan terhitung satu talak, yang berarti ia masih ada kesempatan dua kali talak lagi.

Sedangkan pisah suami istri karena pembatalan perkawinan, hal ini tidak berarti mengurangi bilangan talak, meskipun terjadinya pembatalan perkawinan karena khiyar balig, kemudian kedua suami istri tersebut menikah dengan akad baru lagi, maka suami tetap mempunyai kesempatan tiga kali talak.

Mengenai masa pelaksanaan fasakh, terdapat perbedaan pendapat dikalangan ulama. Imam syafi'i berkata: "harus menunggu selama tiga hari." Sedangkan imam maliki mengtakan: "harus menunggu selama satu bulan." Sedangkan imam hambali mengatakan: "harus menunggu selama satu tahun". 30

Semua itu maksudnya adalah selama masa waktu tersebut laki-laki boleh mengambil keputusan akan bercerai atau memberikan nafkah bila istri tidak rela lagi. Setelah fasakh itu dilakukan, maka perceraian itu

\footnotetext{
${ }^{30}$ Muhammad Abu Zahrah, ......Op.Cit, hlm, 341
} 
dinamakan talak ba'in. Kalau suami hendak kembali kepadanya, maka harus dengan nikah lagi dengan akad baru. Sedang iddahnya sebagai iddah talak biasa. Perbedaan Antara Fasakh dan Talak Terputusnya hubungan perkawinan akibat fasakh, baik disebabkan adanya cacat dalam akad itu sendiri maupun disebabkan sesuatu yang menghambat keberlangsungannya membatalkan akad nikah dan menghentikannya seketika dan secara langsung, seperti yang diakibatkan oleh talak ba'in.

Sehingga batalnya perkawinan seperti dalam kasus perkaran Nomor : 0554/Pdt.G/2009/PA.TA adalah status suami istri akan kembali seperti semula dengan alasan. Pertama, fasakh adalah pembatalan akad dari segi asasnya, dan bekaitan bagi menghilangkan ikatan menyertai (timbul karenanya) sedangkan talak (kecuali talak ba'in kubra) adalah pengakhiran akad tanpa efek menghilangkan kebolehan (hak) untuk melakukan hubungan (kembali). Kedua, fasakh adakalanya terjadi disebabkan bencana di atas akad yang menghilangkan perkawinan itu sendiri, dan adakalanya karena keadaan yang mengiringi akad itu sendiri tidak menghendaki kalangsungan daya ikat sejak asalnya. contoh fasakh karena salah satu pasangan masih berhubungan darah, dan fasakh karena salah satu pasangan masih terikat dengan perkawinan dengan orang lain namun mereka masih punya hak khiyar yang dimiliki masing-masing pasangan setelah baligh untuk meneruskan atau tidak meneruskan perkawinannya yang dilakukan. Ketiga, peristiwa fasakh tidak mengurangi bilanganbilangan talak yang dimiliki suami; sedangkan penjatuhan talak akan mengurangi jumlah bilangan yang ada pada suami.

Jadi pembatalan perkawinan bagi status hukum suami istri adalah pada perkara Nomor 0554/Pdt.G/2009/PA.TA Status keduanya dianggap tidak pernah menikah. Sebab perkawinannya dianggap tidak pernah ada, sehingga setelah perkawinan mereka batal demi hukum maka status mereka adalah perawan dan duda.

Hal tersebut berbeda dengan pendapat hakim pengadilan Agama Tulungagung yang menyatakan bahwa hubungan suami istri di antara 
keduanya menjadi tidak sah. Akan tetapi status hukum pihak suami dan istri tetap dianggap sudah pernah menikah. Status hukum keduanya bukan lagi jejaka atau perawan karena diantara mereka telah terjadi persetubuhan dan mempunyai anak.

Pendapat hakim di atas jika di cari dalam Undang-undang Perkawinan Tahun 1974 maupun KHI tidak ditemukan, dalam salinan putusan perkara yang diputus juga tidak disebutkan kalau status hukum suami istri dianggap sudah pernah pernah menikah.

Sedangkan pada perkara Nomor 0845/Pdt.G/2010/PA.TA status suami istri meski kembali seperti semula namun status hukum mereka tidak sama dengan perkara Nomor 0554/Pdt.G/2009/PA.TA karena penyebab pembatalan perkawinan pada perkara Nomor 0845/Pdt.G/2010/PA.TA adalah adanya pemalsuan identitas yang dilakukan oleh pihak suami, sehingga akibat hukum yang timbul setelah perkawinanya batal demi hukum adalah status suami kembali pada perkawinan yang pertama, karena pada perkara ini pihak suami telah melakukan praktek perkawinan poligami, sedangkan status suami menjadi duda karena pihak suami telah melakukan perkawinan yang ke dua, oleh sebab itu setelah perkawinan yang ke dua batal demi hukum maka statusnya kembali pada perkawinan pertama yang telah berakhir dengan perceraian.

Perbedaan pada kedua perkara tersebut sebenarnya terletak pada alasan atau penyebab perkawinannya batal demi hukum, dalam teori di bab 2 telah dijelaskan bahwa Istilah batal nya perkawinan dapat menimbulkan salah paham, karena terdapat berbagai ragam tentang pengertian batal (nietig) tersebut. Batal berarti nietig zonder kracht (tidak ada kekuatan) zonder waarde (tidak ada nilai). Dapat dibatalkan berarti nietig verklraad, sedangkan absolute nietig adalah pembatalan mutlak.

3. Akibat Hukum Putusan Pembatalan Perkawinan oleh Pengadilan Agama Kabupaten Tulungagung Terhadap Pengasuhan Anak 
Tentang pengasuhan anak pada perkara Nomor 0845/Pdt.G/2010/PA.TA dan perkara 0554/Pdt.G/2009/PA.TA juga terdapat perbedaan yaitu pada perkara Nomor 0845/Pdt.G/2010/PA.TA anak pengasuhan anak diasuh oleh pihak suami sedangkan pihak istri tidak mau mengasuhnya karena merasa sakit hati telah dibohongi oleh suaminya, namun dalam hal status nasab pihak suami dan istri sama mengakui bahwa anak yang lahir dari perkawinanya yang telah dibatalkan adalah tetap anak mereka.

Sedangkan pada perkara Nomor 0554/Pdt.G/2009/PA.TA kedua orang tua meski perkawinannya telah dibatalkan namun dalam pengasuhan anak tetap menjadi tanggung jawab mereka berdua, baik dari pihak suami dan istri sama-sama bertanggung jawab dalam mendidik dan mengasuh anak dari perkawinan yang telah batal demi hukum.

Berdasarkan teori pada bab 2 bagi anak-anak yang orang tuanya telah dibatalkan perkawinannya mereka tetap merupakan anak sah dari ibu dan bapaknya. Oleh karena itu anak-anak tetap menjadi anak sah, maka status nasab, warisan dan akibat perdata lainnya ia mengikuti kedudukan hukum orangtuanya.

Kedua orang tua wajib memelihara dan mendidik anak-anaknya sebaik-baiknya, hal ini berlaku sampai dengan anak tersebut kawin atau dapat berdiri sendiri, dan kewajiban ini terus berlangsung terus walaupun perkawinan antara kedua orang tuanya telah putus.

Hal tersebut sesuai dalam Pasal 75 Kompilasi Hukum Islam disebutkan bahwa akibat hukum terhadap pembatalan perkawinan tidak berlaku surut terhadap:

a. Perkawinan yang batal karena salah satu dari suami atau isteri murtad

b. Anak-anak yang dilahirkan dari perkawinan tersebut 
c. Pihak ketiga sepanjang mereka memperoleh hak-hak dengan beritikad baik, sebelum keputusan pembatalan perkawinan mempunyai kedudukan hukum yang tetap. ${ }^{31}$

Anak-anak yang dilahirkan dalam perkawinan yang telah dibatalkan tidak berlaku surut, sehingga dengan demikian anak-anak ini dianggap sah, meskipun salah seorang tuanya beritikad atau keduanya beritikad buruk. Fakta pada kasus perkara Nomor 0845/Pdt.G/2010/PA.TA dan perkara 0554/Pdt.G/2009/PA.TA kedua orang tua yang sudah batal perkawinannya masih mengakui anaknya sebagai anak yang sah dan merupakan tanggung jawab mereka.

Hal tersebut sesuai dalam Pasal 76 Kompilasi Hukum Islam menentukan bahwa: Batalnya suatu perkawinan tidak akan memutuskan hubungan hukum antara anak dengan orang tuanya. ${ }^{32}$ Seharusnya di dalam perkawinan ini yang berhak menikahkan bertindak sebagai wali nikah merupakan abang kandung dari calon mempelai wanita.

Sedangkan dalam hukum Islam tentang pengasuhan anak setelah perkawinan batal/fasakh adalah:

"Jika anak belum mencapai fase tamyiz (berakal), maka ibu tetap berkewajiban mengasuh anaknya. Jika ibu tidak mampu mengasuh anaknya (misalnya karena : kafir/murtad, tidak waras, dan sebab syar'i lainnya yang tidak memungkinkan dia mengasuh dan mendidik anak), maka pengasuhan dapat dilakukan oleh ibunya ibu (nenek dari anak) hingga garis keturunan seterusnya. Jika dari semua yang tergolong mulai dari ibunya ibu hingga garis keturunan seterusnya tidak mampu mengasuh maka menjadi kewajiban ayah untuk mengasuh atau mencari pengasuh yang mumpuni untuk mengasuh dan mendidik anak-anaknya. Pengasuh yang dipilih bisa ibunya ayah (nenek anak) hingga garis keturunan seterusnya. Bisa juga perempuan lain yang memang mumpuni dalam mengasuh anak. Adapun syarat pengasuh anak adalah baligh dan berakal, mampu mendidik, terpercaya dan berbudi luhur, Islam, dan tidak bersuami". 33

\footnotetext{
${ }^{31}$ Moch. Idris Ramulyo, ....Op.Cit, hlm. 17

${ }^{32}$ Ibid., hlm. 17

${ }^{33}$ Huzaemah Tahido Yanggo, Fiqih Anak, Bandung: Remaja Rosda Karya, hlm.17
} 
Jelasnya dalam hukum Islam setelah perkawinan batal maka yang berkewajiban mengasuh anak adalah ibunya dengan batasan sebelum anak itu tamyiz (berakal). Akibat hukum terhadap hak pengasuhan anak yang dilahirkan dari suatu perkawinan yang dibatalkan adalah bahwa status dari anak yang sah dari keturunan kedua orang tuanya dan kewajiban mendidik dan mengasuh anak menjadi kewajiwab kedua orang tuanya. Anak sah adalah anak yang lahir dari atau sebagai akibat dari perkawinan yang sah sehingga mempunyai hubungan hukum atau hubungan keperdataan terhadap ayah dan ibunya. Sedangkan anak tidak sah ialah anak yang dilahirkan diluar perkawinan, anak tersebut hanya mempunyai hubungan keperdataan dengan ibunya.

Pada Pasal 76 KHI disebutkan bahwa batalnya suatu perkawinan tidak akan memutuskan hubungan hukum antara anak dengan orang tuanya. Dengan demikian jelaslah bahwa di dalam KHI secara eksplisit mengandung dua pengertian pembatalan perkawinan, yaitu perkawinan batal demi hukum seperti yang termuat pada Pasal 70 dan perkawinan yang dapat dibatalkan (relatif) seperti yang terdapat pada Pasal 71. Dan pembatalan perkawinan tidak berpengaruh terhadap status anak yang telah mereka lahirkan seperti yang termuat pada Pasal 76 Kompilasi Hukum Islam.

Sehingga dapat disimpulkan meskipun orang tua beritikat buruk atau tidak mau mengasuh anaknya seperti pada perkara Nomor : 0845/Pdt.G/2010/PA.TA status hukum anak tetaplah anak merena dan kewajiban mengasuh anak tetap menjadi kewajiban kedua orang tuanya.

4. Akibat Hukum Putusan Pembatalan Perkawinan oleh Pengadilan Agama Kabupaten Tulungagung Terhadap Harta yang Diperoleh Selama Masa Perkawinan

Pada perkara Nomor : 0845/Pdt.G/2010/PA.TA dan perkara Nomor : 0554/Pdt.G/2009/PA.TA tentang akibat hukum pembatalan perkawinan terhadap harta bersama/gono gini tidak ada perbedaan, berdasarkan salinan putusan dan wawancara dengan para pihak mereka telah sepakat bahwa 
harta bersama yang didapat selama perkawinan dibagi secara kekeluargaan dan tidak masuk pada materi permohonan sehingga dalam salinan putusan tentang pembagian harta bersama tidak disebutkan oleh majlis hakim.

Pada perkara pembatalan perkawinan karena dalam putusan tidak disebutkan tentang harta bersamadan kedua belah pihak tidak mempermasalahkan, maka keputusan penyelesaian harta bersama diserahkan pada suami isteri untuk membagi secara adil.

Harta bersama adalah harta benda yang diperoleh selama perkawinan menjadi harta bersama dan mengenai harta bersama tersebut suami istri dapat bertindak atas persetujuan kedua belah pihak. Pada persoalan harta bersama ini berlaku ketentuan bahwa jika terjadi perceraian hidup, maka masing-masing berhak mendapatkan sebagian atau separoh dari harta bersama mereka. Jadi terhadap perkawinan yang fasakh karena melanggar larangan perkawinan, maka masing-masing pihak mendapatkan separoh dari harta bersama mereka.

Akibat hukum dari pembatalan perkawinan seperti diuraikan di atas penulis memperoleh suatu kepastian bahwa dalam hal harta bersama sebagai akibat dari pembatalan perkawinan sejauh ini belum ada peraturan yang secara pasti mengatur mengenai status harta bersama tersebut, maupun bagaimana pembagiannya terhadap masing-masing pihak.

Namun hal ini berbeda dengan akibat hukum dari perkawinan yang putus karena perceraian maupun perkawinan yang putus karena kematian, dalam hal status harta bersama perkawinan yang putus karena perceraian maupun perkawinan yang putus karena kematian pengaturannya sudah cukup jelas bahwa terhadap harta bersama menjadi akibat hukumnya dan pembagiannya diatur dalam undang-undang perkawinan Pasal 37, yakni, apabila perkawinan putus karena perceraian, harta bersama diatur menurut hukumnya masing-masing.

Dalam hal pembagian harta bersama terhadap perkawinan yang putus karena perceraian maupun perkawinan yang putus karena kematian, juga diatur dalam kompilasi hukum Islam Pasal 97, janda atau duda cerai 
hidup masingmasing berhak seperdua dari harta bersama sepanjang tidak ditentukan lain dalam perjanjian perkawinan, sedangkan untuk perkawinan yang putus karena kematian diatur dalam Pasal 96 yakni apabila terjadi cerai mati, maka separoh harta bersama menjadi hak pasangan yang hidup lebih lama.

Fakta pada temuan penelitian dalam perkara Nomor 0845/Pdt.G/2010/PA.TA dan perkara 0554/Pdt.G/2009/PA.TA apabila para pihak memilih membagi harta bersama berdasarkan kekeluargaan adalah pilihan yang tepat karena secara hukum belum ada aturan yang mengatur tentang pembagian harta bersama setelah pembatalan perkawinan.

Hal tersebut sesuai dengan teori hukum Islam yang menyatakan bahwa :

"Pembagian harta gono-gini tergantung kepada kesepakatan suami dan istri. Kesepakatan ini di dalam Al Qur'an disebut dengan istilah "ash-Shulhu"yaitu perjanjian untuk melakukan perdamaian antara kedua belah pihak (suami istri) setelah mereka berselisih". 34

Jelasnya apabila pada perkara Nomor : 0845/Pdt.G/2010/PA.TA dan perkara 0554/Pdt.G/2009/PA.TA apabila dikemudian hari terjadi perselisihan tentang harta bersama maka dapat mengajukan gugatan ke Pengadilan Agama.

Pengadilan Agama berwenang menyelesaikan perselisihan harta bersama tersebut, sebagaimana bunyi Pasal 49 Undang-undang Peradilan Agama No. 3 Tahun 2006 sebagai berikut:

"Pengadilan bertugas dan berwenang memeriksa, memutus, dan menyelesaikan perkara di tingkat pertama antara orang-orang yang beragama Islam dalam bidang perkawinan, waris, wasiat, hibah, wakaf, zakat, infaq, shadaqah dan ekonomi syri'ah".

${ }^{34}$ Muhammad Jawad Mughniyah, Op.Cit., hlm. 231 
Harta bersama menjadi akibat hukum dari pembatalan perkawinan, karena pembatalan perkawinan merupakan perkawinan yang putus karena putusan pengadilan, maka apabila ada pihak-pihak yang ingin menyelesaikan masalah perselisihan harta bersama bisa langsung diajukan ke Pengadilan Agama serta yang berhak atas harta bersama adalah suami atau isteri sebagaimana yang telah diatur dalam Undang-undang perkawinan "Pasal 36 ayat 1 Mengenai harta bersama suami atau isteri mempunyai hak sepenuhnya untuk melakukan perbuatan hukum mengenai harta bendanya",35

Dalam perkara pembatalan perkawinan pembagian harta bersama dibagi sama halnya dalam harta bersama sebagai akibat hukum dari putusnya perkawinan karena perceraian, yaitu masing-masing pihak berhak mendapatkan seperdua dari harta bersama, seperti yang ditegaskan dalam kompilasi hukum Islam Pasal 97 yaitu :

"Janda atau duda cerai hidup masing-masing berhak seperdua dari harta bersama sepanjang tidak ditentukan lain dalam perjanjian perkawinan". ${ }^{36}$

Namun hal ini tidak berlaku terhadap perkara pembatalan perkawinan yang mana pembatalan tersebut didasarkan dengan alasan adanya perkawinan terdahulu, maka status harta bersama dianggap tidak pernah ada, oleh karena perkawinan tersebut merupakan poligami liar yang tidak memiliki kekuatan hukum sehingga harta yang diperoleh selama dalam masa perkawinan yang dibatalkan tersebut dianggap tidak pernah ada dan menjadi hak pemilik perkawinan terdahulu. Sebagaimana di jelaskan dalam Undang-undang Nomor 1 Tahun 1974 Pasal 28 Ayat (2) huruf (b), suami atau isteri yang bertindak dengan iktikad baik, kecuali terhadap harta bersama bila pembatalan perkawinan didasarkan atas adanya perkawinan lain yang lebih dahulu.

\footnotetext{
${ }^{35}$ Ibid., hlm. 32

${ }^{36}$ Ibid.,
} 
Jadi baik itu dalam KHI maupun dalam hukum Islam harta bersama salah satu dari kedua belah pihak atau kedua-duanya kadang harus merelakan sebagian hak-nya demi untuk mencapai suatu kesepakatan. Memang temukan di dalam KHI (Kompilasi Hukum Islam) dalam Peradilan Agama, Pasal 97, yang menyebutkan bahwa :

"Janda atau duda cerai hidup masing-masing berhak seperdua dari harta bersama sepanjang tidak ditentukan lain dalam perjanjian perkawinan."

Keharusan untuk membagi sama rata, yaitu masing-masing mendapatkan $50 \%$, seperti dalam KHI di atas, ternyata tidak mempunyai dalil yang bisa dipertanggung jawabkan, sehingga pendapat yang benar dalam pembagian harta bersama adalah dikembalikan kepada kesepakatan antara suami istri. Kesepakatan tersebut berlaku jika masing-masing dari suami istri memang mempunyai andil di dalam pengadaan barang yang telah menjadi milik bersama, biasanya ini terjadi jika suami dan istri samasama bekerja. Namun masalahnya, jika istri di rumah dan suami yang bekerja, maka dalam hal ini tidak terdapat harta bersama, dan pada dasarnya semua yang dibeli oleh suami adalah milik suami, kecuali barang-barang yang telah dihibahkan kepada istri, maka menjadi milik istri.

\section{PENUTUP}

\section{Kesimpulan}

a. Akibat hukum putusan pembatalan perkawinan oleh Pengadilan Agama Kabupaten Tulungagung terhadap status suami dan istri adalah diantara keduanya dianggap tidak pernah terjadi perkawinan. Pada perkara Nomor 0554/Pdt.G/2009/PA.TA status hukum permohon dan termohon kembali pada status semula yaitu secara hukum status mereka menjadi jejaka dan perawan walaupun mereka dianggap telah melakukan persetubuhan. Pada perkara Nomor 0845/Pdt.G/2010/PA.TA status Termohon I kembali ke posisi 
sebelumnya yaitu suami dari istri pertama, sedangkan status Termohon II kembali seperti semula yaitu sebagai istri dari suaminya terdahulu.

b. Akibat hukum putusan pembatalan perkawinan oleh Pengadilan Agama Kabupaten Tulungagung terhadap pengasuhan anak adalah status hukum secara resmi sebagai anak kandung mereka, artinya status anak tetap memiliki hubungan hukum dengan ibu dan ayahnya sehingga anak-anak tersebut berhak pula menjadi ahli waris dengan kedua orang tua mereka. Dan dengan sehubungan dengan kewajiban orang tua terhadap anaknya walaupun perkawinan antara orang tuanya telah batal demi hukum tetapi kewajiban orang tua untuk mendidik dan mengasuh anak hasil perkawinan tersebut tetap harus dilaksanakan sampai anak-anak tersebut dewasa. Pada perkara Nomor 0845/Pdt.G/2010/PA.TA dan perkara 0554/Pdt.G/2009/PA.TA secara hukum jelas bahwa anak hasil dari perkawinan yang dibatalkan tetap menjadi kewajiban orang tua untuk mendidik dan mengasuh anak tersebut hingga dewasa.

c. Akibat hukum putusan pembatalan perkawinan oleh Pengadilan Agama Kabupaten Tulungagung terhadap harta yang diperoleh selama masa perkawinan adalah harta bersama dibagi menjadi dua berdasarkan kesepakatan antara suami dan istri. Pada perkara Nomor 0554/Pdt.G/2009/PA.TA pengadilan agama tidak memutuskan tentang pembagian harta bersama karena para pihak telah sepakat untuk membagi harta bersama secara adil yaitu setengah bagian. Sedangkan pada perkara Nomor 0845/Pdt.G/2010/PA.TA pengadilan agama tidak memutuskan tentang pembagian harta bersama karena para pihak telah sepakat untuk membagi harta bersama secara kekeluargaan 


\section{DAFTAR PUSTAKA}

\section{A. Literatur}

Abdurrahman, Kompilasi Hukum Islam di Indonesia, Jakarta: Akademika Pressindo, 1995.

al-Zuhailiy, Wahbah, Fiqh al-Islamiy wa Adillatuh, cet II, Libanon: Dar Fikr, 1985.

Arto, Mukti, Praktek Perkara Perdata pada Pengadilan Agama, Cet VII, Jogjakarta: Pustaka Pelajar, 2007.

Fajar, A. Mukti, Tentang dan Sekitar Undang-undang Nomor 1 Tahun 1974, Malang: Si Unyil, 1982. Azhar Basyir, Op. Cit h. 13

Harahap, Yahya, Kekuasaan Mahkamah Agung, Pemeriksaan Kasasi dan Peninjauan Kembali Perkara Perdata, Cet. I, Jakarta: Sinar Grafika, 2008.

Ismy Syafriani Nasution : Akibat Hukum Perceraian Terhadap Harta Bersama Berdasarkan Undang-Undang Perkawinan Nomor 1 Tahun 1974 Dan Kompilasi Hukum Islam, 2009.

Khalaf, Abdul Wahhab , Ahkam al-Ahwal al-Syakhsiyyah fi al-Syari'ah alIslamiyyah 'Ala Waqfi Madzhab Abi Hanifah wa Ma 'Alaih al-Amal bi al-Mahakim

Lubis, M.Solly 1994, Filsafat Ilmu dan Penelitian, Bandung, Mandar Maju.

Marzuki, Peter Mahmud 2005, Penelitian Hukum, Kencana, Jakarta.

Mertokusumo, Sudikno, Hukum Acara Perdata Indonesia, Edisi 8, cet I Yogyakarta: Liberty, 2009.

Mufidah, Haruskah Perempuan dan Anak di Korbankan? Panduan Pemula untuk

Pendampingan Korban Kekerasan Terhadap Perempuan dan Anak, Malang: PSG Publishing dan Pilar Media, 2006.

Mufidah, Haruskah Perempuan dan Anak di Korbankan? Panduan Pemula untuk 
Pendampingan Korban Kekerasan Terhadap Perempuan dan Anak, Malang: PSG Publishing dan Pilar Media, 2006

Nuruddin, Amiur dan Azhari Akmal Tarigan, Hukum Perdata Islam Di Indonesia, Studi Kritis Perkembangan Hukum Islam dari Fikih, UU No. 1/1974 Sampai KHI, Jakarta: Kencana, 2006

Nuruddin, Amir dan Azhari Akmal Tarigan, Hukum Perdata Islam Di Indonesia Studi Kritis Perkembangan Hukum Islam Dari Fikih, UU No.1/1974, Sampai KHI Jakarta:Kencana, 2004.

Nuruddin, Amir dan Azhari Amal Tarigan, Hukum Perdata Islam Di Indonesia Studi Kritis Perkembangan Hukum Islam Dari Fikih, UU No.1/1974, Sampai KHI Jakarta:Kencana, 2004.

Raharjo, Satjipto 1994, Pengadilan Agama Sebagai Pengadilan Keluarga, Jakarta PP IKAHI.

Salman, Otje Soemadiningrat dan Anton F. Susanto, Teori Hukum Mengingat, Mengumpulkan dan Membuka Kembali, Bandung, Refika Aditama, 2004.

Sidharta, Arif Pengantar Ilmu Hukum, PT Alumni, Bandung, 2000.

Sidik, Abdullah, Hukum Perkawinan Islam Jakarta: PT. Tintamas Indonesia, 1983.

Snelbecker, dalam Lexy J.Moleong, 2013, Metodologi Penelitian Kualitatif, Bandung, Remaja Rosdakarya.

Soemiyati, Hukum Perkawinan Islam dan Undang-Undang Perkawinan, Yogyakarta, Liberty, 1986

Subekti dan Tjitrosudibio, Kitab Undang-Undang Hukum Perdata (Burgerlijk Wetboek)

Subekti, R. Hukum Perjanjian, Jakarta: Intermasa, 2005.

Sugiono, 2007, Metode Penelitian Kuantitatif, Kualitatif, dan R\&D, Remaja Rosda Karya, Bandung

Syahar, Saidus . Undang-Undang Perkawinan dan Masalah Pelaksanaannya, Bandung: Alumni, 1976. 
Syarfuddin, Amir. Hukum Perkawinan Islam di Indonesia, Antara Fiqh Munakahat dan Undang-undang Perkawinan. dengan tambahan Undang-Undang Perkawinan dan Undang-Undang Pokok Agraria, Jakarta: Pradnya Paramitha.

Tri, Abdullah Wahyuni, Pengadilan Agama di Indonesia Yogyakarta: Pustaka Pelajar Offset, 2004.

Yunus, Mahmud. Hukum Perkawinan dalam Islam, Jakarta : PT. Hidakarya Agung, 1959. 